\title{
Human papillomavirus genotypes distribution among Gabonese women with normal cytology and cervical abnormalities
}

Samira Zoa Assoumou ${ }^{1,2,3}$, Angelique Ndjoyi Mbiguino ${ }^{3}$, Barthelemy Mabika Mabika ${ }^{4}$, Sidonie Nguizi Ogoula ${ }^{4}$, Mohammed El Mzibri ${ }^{5}$,Abdelkrim Khattabi ${ }^{2}$ and My Mustapha Ennaji ${ }^{*}$

\begin{abstract}
Background: Cervical cancer is one of the most common tumors affecting women with a disproportionate mortality occurring in developing countries. Despite the high prevalence of cervical cancer and cervical neoplasia in Gabon, few studies have been performed to evaluate the prevalence and determinants of HPV infection in this country. The aim of this study was to determine the HPV prevalence and distribution in a population of Gabonese women with normal cytology and cervical abnormalities.

Methods: A total of 200 cervical samples collected in the "Departement d'Anatomie et de Cytologie Pathologiques" of the "Faculté de Medecine et des Sciences de la Santé" in Libreville, Gabonwere analyzed. Cytological status was classified according to Bethesda 2001. Nested polymerase chain reaction (PCR) using consensus degenerate PCR primers (MY09/11 and GP5+/6+) was performed for the detection of HPV DNA and HPV typing was done by DNA sequencing.

Results: Cytological analysis showed that $87 \%$ of women had normal cytology ( $n=174 / 200)$. Among the 26 women with cytological abnormalities, predominance $(61.5 \%$; 16/26) of low grade squamous intraepithelial lesion (LSIL) was found and no cervical cancer case was detected. Overall, HPV DNA was detected in $60 \%$ of women (120/200). With respect to the cytological status, HPV DNA was found in $57.5 \%$ of women with normal cervix and $76.9 \%$ of women with abnormal cytology. HPV genotyping was performed on 114 HPV positive cases and revealed the presence of 11 distinct genotypes: 16, 18, 33, 31, 56, 6, 66, 70, 35, 45 and 81. The high risk type HPV 16 was the most common genotype found in all cytological categories. Six HPV positive samples could not be typed by DNA sequencing, probably due to multiple HPV infection. Evaluation of possible risk factors showed that HPV infection was related positively with number of sexual partners $(\geq 3, \mathrm{OR}=2.3 ; 95 \% \mathrm{Cl}, 1.3-4.3)$, history of sexually transmitted infection (Chlamydia, $\mathrm{OR}=1.9 ; 95 \% \mathrm{Cl}, 1.01-3.4$ ) and marital status (single, $\mathrm{OR}=2.0 ; 95 \% \mathrm{Cl}, 1.1-3.5$ ).

Conclusion: The prevalence of HPV infection among Gabonese women is high. Our findings highlight the need to set up a national program to fight cervical cancer, combining Pap smear test and HPV testing, to improve cervical cancer prevention in Gabon.
\end{abstract}

Keywords: Human papillomavirus, Cytology, Gabonese women, HPV testing

\footnotetext{
* Correspondence: m.ennaji@yahoo.fr

${ }^{1}$ Laboratoire de Virologie, Microbiologie et Qualité/ Eco-toxicologie et

Biodiversité, Faculté des Sciences et Techniques, Université Hassan II,

Mohammedia, Maroc

Full list of author information is available at the end of the article
} 


\section{Background}

Human Papillomavirus (HPV) is the most common sexually transmitted infection worldwide $[1,2]$ and several clinical and epidemiological studies have identified this virus as a causative agent of cervical cancer (CC) development [3-5]. More than $40 \mathrm{HPV}$ types infecting the genital tract of women have been identified and sequenced $[6,7]$. Some HPV types, like 6 and 11, are cause of benign condylomas (low risk group; LR) while a wider number of types (HPV 16, 18, 31, 33, 35, 39, 45,51, 52, $56,58,59,68)$ has been proved to be involved in cervical carcinogenesis (high risk group; HR) [8]. The overall prevalence of HPV in women with $\mathrm{CC}$ has been reported to be as high as $99.7 \%$ [3]; and, HPV 16 and HPV 18 are the most frequently reported HPV types, causing approximately $70 \%$ of CC cases worldwide [9].

Worldwide, a good management of CC depends on an early detection of the disease and efficient prophylactic vaccines. Early detection of the disease depends of the use of Pap smear screening test which has largely contributed in decreasing mortality by CC. However, a number of problems with cytology persist and have been well described elsewhere, including sensitivity, quality of samples and the subjectivity of the reading of slides leading to greater number of interpretive errors [10].Recent molecular biological techniques such as HPV-DNA testing, have been found to be effective HPV screening methods and may facilitate early detection of CC in developing regions. HPV DNA testing for cancer-associated HPV DNA offers a very interesting option for early detection of cervical lesions and is now accepted as a viable and validated approach in the management of women with equivocal cytological findings and those without cytological abnormalities [11]. Indeed, women with normal cytology infected by a HR HPV have approximately 100-fold increased risk of developing cervical cancer compared to uninfected women [12].

On the other hand, prophylactic vaccination represents an interesting primary prevention measure against CC. Currently, two HPV-preventive vaccines (Gardasil ${ }^{\bullet}$ and Cervarix $^{\odot}$ ) are widely used. However, the impact of this preventive measure in different geographical regions will be related to the prevalence of the genotypes 16 and 18 in the different population.

In Gabon, like other African countries, $\mathrm{CC}$ is the most common cancer among women. The age-standardized incidence of CC is 19.9 per 100000 women and the mortality is 8.4 per 100000 women [13]. Little is known about HPV prevalence and distribution among Gabonese women. The present study examined the prevalence and distribution of HPV genotypes in Gabonese population and evaluated whether certain factors were associated with HPV infection.

\section{Results}

The cytological results of the 200 samples showed that $87 \%$ had a normal cytology (174/200). Among the 26 women with cytological abnormalities, 8 (30.8 \%) were atypical squamous cell of undetermined significance (ASCUS); 16 (61.5 \%) were low grade squamous sntraepithelial lesion (LSIL); and, only 2 cases (7.7 \%) were classified as high grade squamous intraepithelial lesion (HSIL). In these women, no cytology indicating $\mathrm{CC}$ was observed.

The presence of amplifiable DNA was confirmed in all 200 samples by $\beta$-globin PCR; and, all samples were adequate for further analysis. Results of HPV detection and typing are reported in Table I. Overall, $60 \%$ of participating women harbored HPV DNA (120/200). Moreover, HPV DNA was detected in $57.5 \%$ of women with normal cytology $(100 / 174)$ and $76.9 \%$ of the women with abnormal cytology (20/26). Distribution of HPV according to cervical abnormalities showed that HPV DNA was found in $50 \%$ of ASCUS (4/8), $87.5 \%$ of LSIL cases $(14 / 16)$, and in all the HSIL cases $(2 / 2)$.

HPV genotyping by DNA sequencing was only possible on 114 HPV positive cases and revealed the presence of 11 distinct genotypes and mostly with high oncogenic potential (Table 1). Six HPV positive samples could not be typed. HPV HR DNA was detected in $83.3 \%(80 / 96)$ of HPV positives women with normal cytology and in $77.8 \%(14 / 18)$ of HPV positives abnormal cervices, whereas LR HPV was detected in $16.7 \%$ $(16 / 96)$ of women with normal cytology and in $22.2 \%$ (4/18) of women with abnormal cytology. The distribution of viral genotypes in all HPV positives samples showed clearly the predominance of HPV 16 (59.6\%; 68/114). Moreover, HPV16 was detected in $58.3 \%$ of HPV positives normal cases (56/96) and $66.7 \%$ of women with abnormal cytology (12/18). Overall, the other HR HPV 33, 31 and 56 were detected in $8.8 \%$ (10/114), $3.5 \%(4 / 114)$, and $3.5 \%(4 / 114))$ respectively. HPV 18, 35, 45, and 66 were detected in $1.8 \%$ each $(2 / 114)$. Of particular interest, HPV45 was detected only in cases with abnormal cytology. In this study, LR HPV detected were HPV6, 70 and 81. HPV6 was detected in $14.6 \%$ of HPV positives normal cases (14/96) and in $11.1 \%$ of abnormal cytology HPV positives (2/18). HPV70 was detected only in normal cases $(2.1 \% ; 2 / 96)$, whereas HPV81 was detected only in 2 abnormal cytologies (11.1\%).

HPV prevalence by age group is reported in Fig. 1. $\mathrm{HPV}$ prevalence peaked among women $<25$ years of age and $\geq 55$ years of age. HR HPV prevalence was high across all age groups and showed a slight decline among older women, aged $>55$ years who present the highest proportion of LR HPV.

The relationship between HPV positivity and risk factors such as age, age of the first sexual intercourse, 
Table 1 Distribution of HPV genotypes according to cytological diagnosis

\begin{tabular}{|c|c|c|c|c|c|c|}
\hline & \multirow[t]{2}{*}{ All samples $(n=200)$} & \multirow[t]{2}{*}{ Normal cytology $(n=174)$} & \multicolumn{4}{|c|}{ Abnormal cytology $(n=26)$} \\
\hline & & & $\operatorname{ASCUS}(n=8)$ & LSIL $(n=16)$ & $\mathrm{HSIL}(n=2)$ & Total $(n=26)$ \\
\hline Negative & $80(40.0)$ & $74(42.5)$ & $4(50.0)$ & $2(12.5)$ & $0(0.0)$ & $6(23.1)$ \\
\hline Positve & $120(60.0)$ & $100(57.5)$ & $4(50.0)$ & $14(87.5)$ & $2(100)$ & $20(76.9)$ \\
\hline Undetermined HPV types & $6(5.0)$ & $4(4.0)$ & $2(50.0)$ & - & - & $2(20.0)$ \\
\hline Determined HPV types & $114(95.0)$ & $96(96.0)$ & $2(50.0)$ & $14(100)$ & $2(100)$ & $18(80.0)$ \\
\hline $\mathrm{HR} \mathrm{HPV+}$ & $94(82.5)$ & $80(83.3)$ & $2(100)$ & $10(71.4)$ & $2(100)$ & $14(77.8)$ \\
\hline LR HPV+ & $20(17.5)$ & $16(16.7)$ & - & $4(28.6)$ & - & $4(22.2)$ \\
\hline \multicolumn{7}{|l|}{ HR genotypes } \\
\hline HPV 16 & $68(59.6)$ & $56(58.3)$ & $2(100)$ & $8(57.1)$ & $2(100)$ & $12(66.7)$ \\
\hline HPV 18 & $2(1.8)$ & $2(2.1)$ & & & & \\
\hline HPV 33 & $10(8.8)$ & $10(10.4)$ & & & & \\
\hline HPV 31 & $4(3.5)$ & $4(4.2)$ & & & & \\
\hline HPV 35 & $2(1.8)$ & $2(2.1)$ & & & & \\
\hline HPV 45 & $2(1.8)$ & $0(0.0)$ & & $2(14.3)$ & & $2(11.1)$ \\
\hline HPV 56 & $4(3.5)$ & $4(4.2)$ & & & & \\
\hline HPV 66 & $2(1.8)$ & $2(2.1)$ & & & & \\
\hline \multicolumn{7}{|l|}{ LR genotypes } \\
\hline HPV 6 & $16(14.0)$ & 14 (14.6) & & $2(14.3)$ & & $2(11.1)$ \\
\hline HPV 70 & $2(1.8)$ & $2(2.1)$ & & & & \\
\hline HPV 81 & $2(1.8)$ & $0(0.0)$ & & $2(14.3)$ & & $2(11.1)$ \\
\hline
\end{tabular}

The distribution of HPV genotypes in all cytological categories found is presented in this table

The number in bracket are the percentages

number of sexual partners during lifetime, cigarette smoking, oral contraceptive use, marital status, history of sexual transmitted infection (HIV and Chlamydia Trachomatis) and parity was investigated (Table 2). Statistical analysis showed a statistically significant association between the presence of HPV infection and number of sexual partners $\geq 3$ during lifetime $(\mathrm{OR}=2.3$;
$95 \%$ CI, 1.3-4.3); being single (OR $=2.0$; $95 \%$ CI, 1.1-3.5) and infection with Chlamydia trachomatis (OR $=1.9 ; 95 \%$ CI, 1.01-3.4).

Other risks such as age, parity, age of the first sexual intercourse, oral contraceptive use, cigarette smoking, had no statistically significant association with HPV infection $(p>0.05)$.

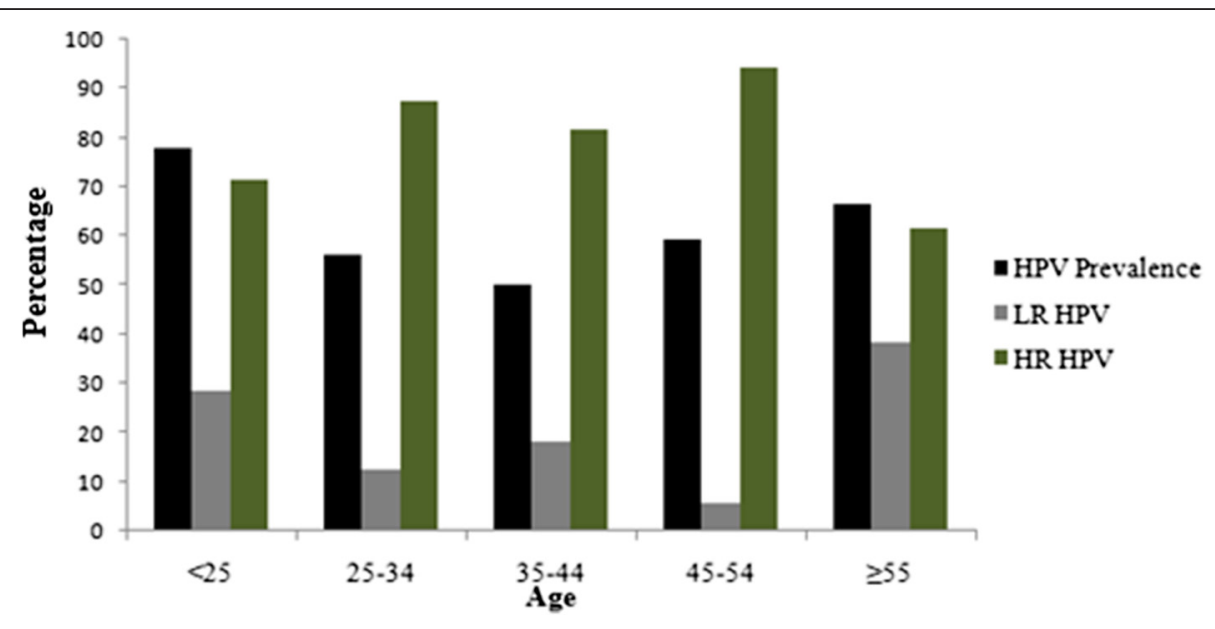

Fig. 1 Age specific prevalence of HPV DNA among Gabonese women studied 
Table 2 Potential risk factors associated with HPV infection in the Gabonese women

\begin{tabular}{|c|c|c|c|c|c|}
\hline Characteristics & N & $\mathrm{HPV}+$ & HPV- & ${ }^{\mathrm{a}} \mathrm{OR}(95 \% \mathrm{Cl})$ & $P$ \\
\hline \multicolumn{6}{|l|}{ Age } \\
\hline$<25$ & 18 & $14(77.8)$ & $4(22.2)$ & $1.8(0.5-6.3)$ & \multirow[t]{5}{*}{0.4} \\
\hline $25-34$ & 32 & $18(56.3)$ & $14(43.7)$ & $0.6(0.3-1.7)$ & \\
\hline $35-44$ & 44 & $22(50.0)$ & $22(50.0)$ & $0.5(0.2-1.2)$ & \\
\hline $45-54$ & 64 & $38(59.4)$ & $26(40.6)$ & $0.7(0.3-1.7)$ & \\
\hline$>55$ & 42 & $28(66.7)$ & $14(3.33)$ & 1 & \\
\hline \multicolumn{6}{|l|}{ Marital status } \\
\hline Single (Never married/Separated/Widowed) & 90 & $62(68.9)$ & $28(31.1)$ & $2.0(1.1-3.5)$ & \multirow[t]{2}{*}{0.02} \\
\hline Living with partner/Married & 110 & $58(52.8)$ & $52(47.2)$ & 1 & \\
\hline \multicolumn{6}{|l|}{ Age of the first sexual intercourse } \\
\hline$<18$ & 120 & $70(58.3)$ & $50(41.7)$ & $0.8(0.5-1.5)$ & \multirow[t]{2}{*}{0.6} \\
\hline$\geq 18$ & 80 & $50(62.5)$ & $30(37.5)$ & 1 & \\
\hline \multicolumn{6}{|l|}{ Number of sexual partners during lifetime } \\
\hline$<3$ & 61 & $28(45.9)$ & $33(54.1)$ & 1 & \multirow[t]{2}{*}{0.007} \\
\hline$\geq 3$ & 139 & $92(66.2)$ & $47(33.8)$ & $2.3(1.3-4.3)$ & \\
\hline \multicolumn{6}{|l|}{ Smoking } \\
\hline No & 196 & $116(59.2)$ & $80(40.8)$ & 1 & \multirow[t]{2}{*}{0.15} \\
\hline Yes & 4 & $4(100)$ & $0(0.0)$ & $1.5(1.1-2.1)$ & \\
\hline \multicolumn{6}{|l|}{ Oral contraception use } \\
\hline Yes & 2 & $1(50.0)$ & $1(50.0)$ & $0.7(0.04-11.0)$ & \multirow[t]{2}{*}{0.8} \\
\hline No & 198 & $118(59.6)$ & $80(40.4)$ & 1 & \\
\hline \multicolumn{6}{|l|}{ Parity } \\
\hline 0 & 26 & $14(53.9)$ & $12(46.1)$ & 1 & \multirow[t]{3}{*}{0.4} \\
\hline $1-3$ & 62 & $36(58.1)$ & $26(41.9)$ & $1.2(0.5-3.0)$ & \\
\hline$>3$ & 112 & $70(62.5)$ & $42(37.5)$ & $1.4(0.6-3.4)$ & \\
\hline \multicolumn{6}{|l|}{ History of STI } \\
\hline No & 126 & $68(54.0)$ & $58(46.0)$ & 1 & \multirow[t]{3}{*}{0.03} \\
\hline Chlamydia trachomatis & 70 & $48(68.6)$ & $22(31.4)$ & $1.9(1.0-3.4)$ & \\
\hline HIV & 4 & $4(100)$ & $0(0.0)$ & $7.7(0.4-145.8)$ & \\
\hline
\end{tabular}

Some risk factors of HPV infection were evaluated. This table provides information about the association found between HPV infection and some risk factors among the Gabonese women studied

The number in bracket are the percentages

${ }^{a}$ All the considered variables were used in a multivariate logistic regression analysis

\section{Discussion}

Worldwide, HPV testing for cancer-associated HPV DNA is now accepted as a viable and validated option in the management of women with equivocal cytology findings; and, in the last few years, there has been an increasing interest in using the HPV testing also in cervical samples from asymptomatic women without cytological abnormalities [14]. This strategy seems to allow an early identification of populations at different risk level for this neoplasia because of the close relationship between HPV infection and cervical cancer development.

In Gabon, there is no national organized CC screening program. However, some efforts are made to reduce the prevalence of cervical cancer by organisation of screening campaigns in order to detect women with cervical cancer disease or precancerous lesions for an early and effective management. However, few data are available on the prevalence of HPV in the Gabonese population and distribution of HPV genotypes. Thus, the aim of this work is to characterize HPV genotype circulating in Gabon and highlight the interest of introducing HPV testing in the global management of cervical cancer and precancerous lesions.

Not surprisingly for a sub-Saharan Africa country, our finding showed a high HPV prevalence (60\%). Indeed comparable rates were also reported in Equatorial Guinea (60 \%) [15], in Conakry Guinea (51.5 \%) [16], in 
Kenya (44.3\%) [17] and in Nigeria (37 \%) [18]. A previous study conducted by Si-Mohammed et al. [19] on women of childbearing age living in Libreville-Gabon reported the presence of HPV DNA in $46 \%$ of cases. This difference is probably due to the sensitivity of the method used for HPV detection. In the previous Gabonese HPV study, HPV DNA was detected by standard PCR using the MY09/MY11 primer set, whereas a nested PCR using MY09/11 and GP5+/6+ was used in our study. There is evidencethat nested PCR is more sensitive and allows to reduce false negative cases [20].

The overall prevalence of HR-HPV found in our study was $82.5 \%$ of HPV positive cases which is in agreement with some reported datain two studies conducted in Burkina Faso and in Benin [21, 22]. Moreover, HPV 16 was the most predominant genotype from HPV positives samples representing $59.6 \%$ of cases. Thisgenotype was also the most prevalent in all cytological categories. This finding well corroborate with previously reported results from many parts of the world [23-25]. However, in some African studies, HPV16 is not usually the predominant genotype, as it was reported in Benin where HPV16 ranked third after HPV59 and 35 [22], and in Burkina Faso, where HPV 52, 35 and 58 were the most prevalent genotypes [26].

To our knowledge, this is the first study providing information about HPV genotypes distribution in regard to cytological status among Gabonese women. HPV DNA was detected in $57.5 \%$ of women with normal cytology and many of them harbor HR HPV. These results are alarming in comparison with the worldwide HPV prevalence among women with normal cervical cytology, reported to be $10.4 \%$ [27]. In Africa, similar studies have reported less prevalence, as it's the case in Morocco (15.8 \%) [28] and in Benin (26.7 \%) [22]. Variations between studies most likely reflect differences in the population studied with respect to risk factors for exposure to HPV [29]. Moreover, the high prevalence of HPV in women with normal cytology could be explained by the low sensitivity of the Pap smear test. Indeed, the quality of sampling and the subjectivity of the reading of slides generate a high rate of false negative results, ranging from 20 to $45 \%$ [10, 30, 31].

For women with cervical abnormalities, HPV was found at a high rate of $76.9 \%$. HPV DNA was detected in $87.5 \%$ of LSIL cases and in all the HSIL cases. HPV 16 was found in $57.1 \%$ of the LSIL and, it was the unique genotype found in HSIL cases. These findings highlight the fact that HPV prevalence increased with the severity of cervical lesions and HPV 16 has a greater capacity than the other genotypes to persist longer in the cervix and induce cervical alterations [32, 33].

In this study, $6 \mathrm{HPV}$ positive cases could not be typed. These specimens could very probably harbor multiple infections and therefore could not be typed by DNA sequencing. DNA sequencing technique has been facing limitation when the specimen harbors multiple genotypes. Other genotyping approach would be used to determine the exact HPV types in theses specimens, like PCR-dot blot hybridization with specific probes or reverse line blot assays including the Linear Array HPV genotyping assay (LA), INNO-LiPA HPV Genotyping Extra (LiPA) and the reverse hybridization assay $(\mathrm{RH})$ [34] in our future studies.

Previous studies have showed that age-standardized HPV prevalence varied more than 10-fold between populations [35]. HPV prevalence peaked in younger women and decline with age in Nigeria [18] and United States [36], however; a second peak was found in older women in Mexico [37] and Senegal [38]. Other countries such as Kenya [39] and Ethiopia [40] exhibited a high HPV prevalence across all age groups. In this study, high peaks of prevalence were found in women $<25$ years and women $\geq 55$ years old. The high HPV prevalence among younger women may coincide with the initiation of sexual activity [37]. Moreover the high HPV prevalence among older women may be explained by HPV persistence and/or new incident infections due to changing sexual behavior and age-related changes of mucosal biology and immune competence [40].

Some risk factors have been identified to increase the risk of having an HPV infection and acting in conjunction with HPV to induce cervical cancer, such as age, parity, oral contraceptive, cigarette smoking, age of first sexual intercourse, marital status, and history of sexual transmitted infections(STI) such as Chlamydia trachomatis and HIV [41, 42]. Indeed, some studies reported that the presence of Chlamydia trachomatis raises the acquisition and the persistence of HPV infection [43, 44] and seems to facilitate the penetration of HPV and the progress of cervical lesions by interfering in the immunological responses [45]. Women living with HIV are also at increased risk for HPV infection [46]. In our study, no statistically significant association between HPV infection and the other risk factors such as age of participants, age of sexual first intercourse, and parity were found. However, statistically significant association was found between HPV infection and number of sexual partner during lifetime, history of STI, and marital status.This finding highlights that only risk factors related to sexual components are associated with HPV infection, and therefore can reflect the sexual behaviors change in Gabonese population.

Considerable efforts have been made to set up a prophylactic vaccination strategy to prevent against HPV infection and persistence. Thus, characterization of HPV types circulating in Gabon is of a great interest and is an essential component for the future application of 
prophylactic vaccines. However, other studies have to be conducted for better characterization of HPV distribution and dissemination in Gabon, including the follow up ofHPV positive women to evaluate the persistence/ clearance of HPV, evaluation of others risk factors of HPV transmission such as the husband's sexual behavior as well as knowledge of Gabonese women about cervical cancer and screening, and acceptance of HPV vaccine.

\section{Conclusion}

Despite the low number of participants, our study confirms the high prevalence of HPV infection in Gabon. Moreover, a broad spectrum of HPV distribution was found in women with normal cytology. These findings highlight that in addition to Pap smear, HPV testing should be considered, and will offer a significant opportunity for the Gabonese National Health Program to control cervical cancer disease and save women lives. These data can also help in the future to monitor the impact of vaccination in Gabon.

\section{Methods}

\section{Study population and sample collection}

A total of 200 participants were recruited between January and June 2012 among women screened for cervical cancer in the "Departementd' Anatomieet de CytologiePathologiques" of the "Faculté de Medecine et des Sciences de la Santé" in Libreville, Gabon. The reason of these women for seeking care was the recommendation of their doctor after some gynecological problems such as pelvic pain, vaginal discharge or pruritus. The women participating in the study ranged in age from 19 to 67 years, the mean age was 43.78 years. The majority of participants (63\%) were undergoing cervical cancer screening for the first time. All participants were to complete questionnaires, including socio-demographic characteristics such as age, occupation, marital status, and parity; and an assessment of their medical and sexual histories: the age of first sexual activity, number of sexual partners during lifetime, antecedent of STI, cigarette smoking, oral contraceptive use and the previous pap smears testing.

Each participant underwent a gynecological examination and collection of two samples of exfoliated cells. The first sample was usedfor cytology diagnosis that was done in the Anatomy Department and Pathological Cytology of the "Faculté de Medecine et des Sciences de la Santé", Libreville-Gabon. Cytological diagnosis was done in turnby two anatomy-pathologists (one after the other) and the final conclusion was taken by consensus according to Bethesda system 2001 [47]. The second sample was suspended in the ThinPrep preservative solution and stored at $-20{ }^{\circ} \mathrm{C}$, then routed to the Virology and Microbiology Laboratory in the "Faculté des Sciences et Techniques de Mohammedia" in Morocco, for the molecular study.

The study was approved by Ethical Committees of the "Ministère de la Santé de Libreville; N00287/MS/SG", and written informed consent was obtained from each study subject.

\section{DNA isolation}

After a brief centrifugation at $12000 \mathrm{~g}$ for cells recuperation, a lysis buffer (SDS $5 \%$, Tris- $\mathrm{HCl} 0.5 \mathrm{M} \mathrm{pH} 8.0$, EDTA $0.1 \mathrm{M}$ and $\mathrm{NaCl} 2.5 \mathrm{M}$ ) containing proteinase $\mathrm{K}$ $(10 \mathrm{mg} / \mathrm{ml})$ was added. DNA was isolated using standard phenol chloroform method and ethanol precipitation. Then, DNA was resuspended in ultrapure water and stored at $-20{ }^{\circ} \mathrm{C}$ until use.

\section{HPV detection and typing}

To evaluate the efficiency of the extraction, integrity of specimen and absence of PCR inhibitors, all extracted DNA were subject to an amplification of $\beta$-globin reference gene using the primers pair PCO4/GH20 [48].

HPV detection and typing was carried out by nested PCR using the L1 consensus primers MY09/11 and GP5+/6+ [49] and DNA direct sequencing [50]. The MY and $\mathrm{GP}+$ primers amplified respectively a fragment of 450 and $150 \mathrm{bp}$. PCR reactions were performed in a total volume of $25 \mu \mathrm{l}$ of the reaction mixture containing $10 \mathrm{mM}$ of dNTP, $2.5 \mathrm{mM}$ of $\mathrm{Mgcl}_{2}, 0.2 \mathrm{U}$ of GoTaq DNA polymerase, and $10 \mu \mathrm{M}$ of $\mathrm{MY}$ orGP+ primers in $1 \mathrm{X}$ Taq polymerase buffer. For the GP+ PCR, $2 \mu$ l of the MY PCR products was used as template.PCR amplification was performed in a Perkin Elmer 2400 GeneAmpR $^{\oplus}$ PCR thermal Cycler (Scientific Support, Inc, Hayward, CA), and was started with an initial denaturation step $\left(95{ }^{\circ} \mathrm{C}\right.$ for $10 \mathrm{~min})$, followed by 40 cycles of $95{ }^{\circ} \mathrm{C}$ for $1 \mathrm{~min}$, annealing temperature $\left(55^{\circ} \mathrm{C}\right.$ for $\mathrm{MY}$ primers and $48{ }^{\circ} \mathrm{C}$ for $\mathrm{GP}+$ primers) for $1 \mathrm{~min}$ and $72{ }^{\circ} \mathrm{C}$ for $1 \mathrm{~min}$; a final extension of $7 \mathrm{~min}$ at $72{ }^{\circ} \mathrm{C}$ was performed. For every reaction, ultrapure water was used as a negative control and DNA extracted from $\mathrm{SiHa}$ cell line was used as positive control. PCR products were analyzed on a $2 \%$ agarose gel stained with Ethidium bromide and visualized by UV light.

HPV genotyping was performed by DNA sequencing. The PCR products were purified using the ExoSaP-IT clean up system (USB, USA) and the sequencing reaction was performed using GP6+ primer as the sequencing primerwith the BigDye Terminator v3.1 Cycle Sequencing kit (Applied Biosystems, Foster City, CA, USA) on an ABI 3130 XL DNA analyzer (Applied Biosystems, Foster City, CA, USA) according to manufacturer's protocol.

The sequences were analyzed by MEGA software version 6.0.5 (www.megasoftware.net). The BLAST server 
(http://www.ncbi.nlm.nih.gov/blast/) was used to match all sequences available in GenBank database. At least $90 \%$ identities matching between the query and subject sequences were required for genotyping [50].

\section{Statistical analysis}

Data were analyzed using Epi info7 software (available in www.cdc.gov). Chi-square of pearson and Fisher exact tests were used when appropriate. To examine some risk factors associated with HPV infection among Gabonese women; all the considered variables were used in a multivariate logistic regression analysis. Odds ratio (OR) with $95 \%$ confidential interval $(\mathrm{CI})$ was used to evaluate the strength of an association. The significance level was considered when $p<0.05$.

\section{Competing interests}

The authors declare they have no competing interests.

\section{Authors' contributions}

SZA Principal Investigator of the study interpreted the data and drafted the manuscript.ANM gave advices for draft the manuscript and revising the manuscript critically. BMM and SNO performed the cytological study and interpreted the results. AK, MM and MME critically revised the manuscript. All authors read and approved the final manuscript.

\section{Acknowledgements}

We are grateful to all the participantwomen who provided their time, biological samples and personal information. Special thanks to Ms. Sophia Azizet and Dr. NzeNguema Florence for assisting in the preparation of the cytological smears.This projectwasfinanciallysupportedby the "Ministère de I'Enseignement Supérieur, de la Recherche Scientifique et la Formation des Cadres" of Morocco. Authors would like to thank the UATRS-CNRST staff for their excellent scientific and technical assistance

\section{Author details}

${ }^{1}$ Laboratoire de Virologie, Microbiologie et Qualité/ Eco-toxicologie et Biodiversité, Faculté des Sciences et Techniques, Université Hassan II, Mohammedia, Maroc. ${ }^{2}$ Département de biologie, Laboratoire d'Agroalimentaire et Santé, Faculté des Sciences et Techniques, Université Hassan I, Settat, Maroc. ${ }^{3}$ Département de Bactériologie et Virologie, Laboratoire de référence MST/Sida, Laboratoire de Référence Rougeole, Rubéole et Fièvre Jaune, Faculté de Médecine et des Sciences de la Santé, Université des Sciences de la Santé, Libreville, Gabon. ${ }^{4}$ Département d'Anatomie et de Cytologie Pathologiques, Faculté de Médecine et des Sciences de la Santé, Université des Sciences de la Santé, Libreville, Gabon. ${ }^{5}$ Unité de Biologie et Recherche Médicale, Centre National de l'Energie, des Sciences et Techniques Nucléaires (CNESTEN), Rabat, Maroc.

Received: 15 January 2015 Accepted: 5 January 2016

Published online: 15 January 2016

\section{References}

1. Koutsky L. Epidemiology of Genital Human Papillomavirus Infection. Am J Med. 1997;102(5):3-8.

2. Sammarco ML, Del Riccio I, Tamburro M, Grasso GM, Ripabelli G. Typespecific persistence and associated risk factors of human papillomavirus infections in women living in central Italy. Eur J Obstet Gynecol Reprod Biol. 2013;168(2):222-6. doi:10.1016/j.ejogrb.2013.01.012.

3. Walboomers JM, Jacobs MV, Manos MM, Bosch FX, Kummer JA, Shah KV, et al. Human papillomavirus is a necessary cause of invasive cervical cancer worldwide. J Pathol. 1999;189(1):12-9.

4. Bosch FX, Manos MM, Munoz N, Sherman M, Jansen AM, Peto J, et al. Prevalence of human papillomavirus in cervical cancer: a worldwide perspective. International biological study on cervical cancer (IBSCC) Study Group. J Natl Cancer Inst. 1995;87(11):796-802.
5. Lalaoui K, El Mzibri M, Amrani M, Belabbas MA, Lazo PA. Human papillomavirus DNA in cervical lesions from Morocco and its implications for cancer control. Clin Microbiol Infect. 2003;9(2):144-8.

6. de Villiers EM, Fauquet $\mathrm{C}$, Broker TR. Bernard HU, zur Hausen H. Class Papillomaviruses Virol. 2004;324(1):17-27. doi:10.1016/j.virol.2004.03.033.

7. Bernard HU, Burk RD, Chen Z, van Doorslaer K. zur Hausen $H_{\text {, }}$ de Villiers EM. Classification of papillomaviruses (PVS) based on 189 PV types and proposal of taxonomic amendments. Virology. 2010;401(1):70-9. doi:10.1016/j.virol.2010.02.002.

8. IARC. Biological agents. Volume $100 \mathrm{~B}$. A review of human carcinogens. IARC monographs on the evaluation of carcinogenic risks to humans/World Health Organization, International Agency for Research on Cancer. 2012;100(Pt B):1-441.

9. WHO/ICO Information Centre on HPV and Cervical Cancer (HPV Information Centre). Human Papillomavirus and Related Cancers in World. Summary Report 2010. http://www.who.int/hpvcentre. Accessed 10 October 2013.

10. Cuzick J, Clavel C, Petry KU, Meijer CJ, Hoyer H, Ratnam S, et al. Overview of the European and North American studies on HPV testing in primary cervical cancer screening. Int J Cancer J Int du Cancer. 2006;119(5):1095-101. doi:10.1002/ijc.21955.

11. Cox T, Cuzick J. HPV DNA testing in cervical cancer screening: from evidence to policies. Gynecol Oncol. 2006;103(1):8-11. doi:10.1016/j.ygyno.2006.07.030.

12. Kaur P, Aggarwal A, Nagpal M, Oberoi L, Sharma S. Prevalence and clinical utility of human papilloma virus genotyping in patients with cervical lesions. J Obstet Gynaecol India. 2014;64(4):279-83. doi:10.1007/s13224-014-0508-5.

13. Ferlay J, Soerjomataram I, Ervik M, Dikshit R, Eser S, Mathers C, et al. GLOBOCAN 2012 v1.0, Cancer Incidence and Mortality Worldwide: IARC CancerBase No. 11 [Internet]. Lyon, France: International Agency for Research on Cancer; 2013. http://globocan.iarc.fr. Accessed on 17 April 2014.

14. Centurioni MG, Puppo A, Merlo DF, Pasciucco G, Cusimano ER, Sirito R, et al. Prevalence of human papillomavirus cervical infection in an Italian asymptomatic population. BMC Infect Dis. 2005;5:77. doi:10.1186/1471-2334-5-77.

15. Garcia-Espinosa B, Nieto-Bona MP, Rueda S, Silva-Sanchez LF, Piernas-Morales MC, Carro-Campos P, et al. Genotype distribution of cervical human papillomavirus DNA in women with cervical lesions in Bioko. Equatorial Guinea Diagn Pathol. 2009:4:31. doi:10.1186/1746-1596-4-31.

16. Keita N, Clifford GM, Koulibaly M, Douno K, Kabba I, Haba M, et al. HPV infection in women with and without cervical cancer in Conakry, Guinea. Br J Cancer. 2009;101(1):202-8. doi:10.1038/sj.bjc.6605140.

17. De Vuyst H, Steyaert S, Van Renterghem L, Claeys P, Muchiri L, Sitati S, et al. Distribution of human papillomavirus in a family planning population in nairobi, kenya. Sex Transm Dis. 2003;30(2):137-42.

18. Akarolo-Anthony SN, Famooto AO, Dareng EO, Olaniyan OB, Offiong R, Wheeler CM, et al. Age-specific prevalence of human papilloma virus infection among Nigerian women. BMC Public Health. 2014;14:656. doi:10.1186/1471-2458-14-656.

19. Si-Mohamed A, Ndjoyi-Mbiguino A, Cuschieri K, Onas IN, Colombet I, Ozouaki F, et al. High prevalence of high-risk oncogenic human papillomaviruses harboring atypical distribution in women of childbearing age living in Libreville, Gabon. J Med Virol. 2005;77(3):430-8. doi:10.1002/jmv.20472.

20. Tornesello ML, de Rosa N, Sarappa F, Buonaguro L, Piccoli R, Buonaguro FM. Assessment of Chlamydia trachomatis infection among Eastern European and West African women immigrants in South Italy. Sex Transm Infect. 2012;88(1):70-1. doi:10.1136/sextrans-2011-050361.

21. Ouedraogo CM, Djigma FW, Bisseye C, Sagna T, Zeba M, Ouermi D, et al. Epidemiology, characterization of genotypes of human papillomavirus in a population of women in Ouagadougou. J Gynecol Obstet Biol Reprod. 2011;40(7):633-8. doi:10.1016/j.jgyn.2011.05.012.

22. Piras F, Piga M, De Montis A, Zannou AR, Minerba L, Perra MT, et al. Prevalence of human papillomavirus infection in women in Benin. West Africa Virol J. 2011;8:514. doi:10.1186/1743-422X-8-514.

23. Clifford GM, Smith JS, Plummer M, Munoz N, Franceschi S. Human papillomavirus types in invasive cervical cancer worldwide: a meta-analysis. Br J Cancer. 2003:88(1):63-73. doi:10.1038/sj.bjc.6600688.

24. Clifford GM, Franceschi S, Diaz M, Munoz N, Villa LL. Chapter 3: HPV typedistribution in women with and without cervical neoplastic diseases. Vaccine. 2006;24 Suppl 3:S3/26-34. doi:10.1016/j.vaccine.2006.05.026.

25. Bruni L, Diaz M, Castellsague X, Ferrer E, Bosch FX, de Sanjose S. Cervical human papillomavirus prevalence in 5 continents: meta-analysis of 1 million women with normal cytological findings. J Infect Dis. 2010;202(12):1789-99. doi:10.1086/657321. 
26. Didelot-Rousseau MN, Nagot N, Costes-Martineau V, Valles X, Ouedraogo A, Konate I, et al. Human papillomavirus genotype distribution and cervical squamous intraepithelial lesions among high-risk women with and without HIV-1 infection in Burkina Faso. Br J Cancer. 2006;95(3):355-62. doi:10.1038/sj.bjc.6603252.

27. de Sanjose S, Diaz M, Castellsague X, Clifford G, Bruni L, Munoz N, et al. Worldwide prevalence and genotype distribution of cervical human papillomavirus DNA in women with normal cytology: a meta-analysis. Lancet Infect Dis. 2007;7(7):453-9. doi:10.1016/S1473-3099(07)70158-5.

28. Alhamany Z, El Mzibri M, Kharbach A, Malihy A, Abouqal R, Jaddi $H$, et al. Prevalence of human papillomavirus genotype among Moroccan women during a local screening program. J Infect Dev Ctries. 2010;4(11):732-9.

29. Dursun P, Senger SS, Arslan H, Kuscu E, Ayhan A. Human papillomavirus (HPV) prevalence and types among Turkish women at a gynecology outpatient unit. BMC Infect Dis. 2009;9:191. doi:10.1186/1471-2334-9-191.

30. Fernandes JV, Meissner Rde V, de Carvalho MG, Fernandes TA, de Azevedo PR, Villa LL. Prevalence of HPV infection by cervical cytologic status in Brazil. Int J Gynaecol Obstet. 2009;105(1):21-4. doi:10.1016/j.ijgo.2008.12.004.

31. Clavel C, Dalstein V, Birembaut P. Stratégies de dépistage des lésions précancéreuses du col de l'utérus : cytologie ou test HPV? septembre-octobre 2008; 38(405):57-65.

32. Schiffman M, Kjaer SK. Chapter 2: Natural history of anogenital human papillomavirus infection and neoplasia. J Natl Cancer Inst Monogr. 2003;31:14-9.

33. Monsonego J, Zerat L, Syrjanen K, Zerat JC, Smith JS, Halfon P. Prevalence of type-specific human papillomavirus infection among women in France: Implications for screening, vaccination, and a future generation of multivalent HPV vaccines. Vaccine. 2012;30(35):5215-21. doi:10.1016/j.vaccine.2012.06.013.

34. Steinau M, Onyekwuluje JM, Scarbrough MZ, Unger ER, Dillner J, Zhou T. Performance of commercial reverse line blot assays for human papillomavirus genotyping. J Clin Microbiol. 2012;50(5):1539-44. doi:10.1128/JCM.06576-11.

35. Franceschi S, Herrero R, Clifford GM, Snijders PJ, Arslan A, Anh PT, et al. Variations in the age-specific curves of human papillomavirus prevalence in women worldwide. Int J Cancer J Int du Cancer. 2006;119(11):2677-84. doi:10.1002/ijc.22241.

36. Dunne EF, Fey PD, Kludt P, Reporter R, Mostashari F, Shillam P, et al. Emergence of domestically acquired ceftriaxone-resistant Salmonella infections associated with AmpC beta-lactamase. JAMA. 2000;284(24):3151-6.

37. Lopez Rivera MG, Flores MO, Villalba Magdaleno JD, Sanchez MV. Prevalence of human papillomavirus in women from Mexico City. Infect Dis Obstet Gynecol. 2012;2012:384758. doi:10.1155/2012/384758.

38. Xi LF, Toure P, Critchlow CW, Hawes SE, Dembele B, Sow PS, et al. Prevalence of specific types of human papillomavirus and cervical squamous intraepithelial lesions in consecutive, previously unscreened, West-African women over 35 years of age. Int J Cancer J Int du Cancer. 2003;103(6):803-9. doi:10.1002/ijc.10876.

39. De Vuyst H, Parisi MR, Karani A, Mandaliya K, Muchiri L, Vaccarella S, et al. The prevalence of human papillomavirus infection in Mombasa. Kenya Cancer Causes Control. 2010;21(12):2309-13. doi:10.1007/s10552-010-9645-z.

40. Leyh-Bannurah SR, Prugger C, de Koning MN, Goette H, Lelle RJ. Cervical human papillomavirus prevalence and genotype distribution among hybrid capture 2 positive women 15 to 64 years of age in the Gurage zone, rural Ethiopia. Infect Agent Cancer. 2014;9(1):33. doi:10.1186/1750-9378-9-33.

41. Castellsague $X$, Bosch FX, Munoz N. Environmental co-factors in HPV carcinogenesis. Virus Res. 2002;89(2):191-9.

42. Syrjanen K, Shabalova I, Petrovichev N, Kozachenko V, Zakharova T, Pajanidi J, et al. Smoking is an independent risk factor for oncogenic human papillomavirus (HPV) infections but not for high-grade CIN. Eur J Epidemiol. 2007;22(10):723-35. doi:10.1007/s10654-007-9180-8.

43. Silins I, Ryd W, Strand A, Wadell G, Tornberg S, Hansson BG, et al. Chlamydia trachomatis infection and persistence of human papillomavirus. Int J Cancer J Int du Cancer. 2005;116(1):110-5. doi:10.1002/ijc.20970.

44. Lehtinen M, Ault KA, Lyytikainen E, Dillner J, Garland SM, Ferris DG, et al. Chlamydia trachomatis infection and risk of cervical intraepithelial neoplasia. Sex Transm Infect. 2011;87(5):372-6. doi:10.1136/sti.2010.044354.

45. Seraceni S, De Seta F, Colli C, Del Savio R, Pesel G, Zanin V, et al. High prevalence of hpv multiple genotypes in women with persistent chlamydia trachomatis infection. Infectious Agents Cancer. 2014;9(30):1-7.
46. De Vuyst $\mathrm{H}$, Ndirangu G, Moodley M, Tenet V, Estambale B, Meijer CJ, et al. Prevalence of human papillomavirus in women with invasive cervical carcinoma by HIV status in Kenya and South Africa. Int J Cancer J Int du Cancer. 2012;131(4):949-55. doi:10.1002/ijc.26470.

47. Apgar BS, Zoschnick L, Wright Jr TC. The 2001 Bethesda System terminology. Am Fam Physician. 2003;68(10):1992-8.

48. Qmichou Z, Khyatti M, Berraho M, Ennaji MM, Benbacer L, Nejjari C, et al. Analysis of mutations in the E6 oncogene of human papillomavirus 16 in cervical cancer isolates from Moroccan women. BMC Infect Dis. 2013;13(1):378 doi:10.1186/1471-2334-13-378.

49. Lee SH, Vigliotti VS, Vigliotti JS, Pappu S. Routine human papillomavirus genotyping by DNA sequencing in community hospital laboratories. Infectious Agents Cancer. 2007;2:11. doi:10.1186/1750-9378-2-11.

50. Lee SH, Vigliotti VS, Vigliotti JS, Pappu S. Validation of human papillomavirus genotyping by signature DNA sequence analysis. BMC Clin Pathol. 2009;9:3. doi:10.1186/1472-6890-9-3.

\section{Submit your next manuscript to BioMed Central and we will help you at every step:}

- We accept pre-submission inquiries

- Our selector tool helps you to find the most relevant journal

- We provide round the clock customer support

- Convenient online submission

- Thorough peer review

- Inclusion in PubMed and all major indexing services

- Maximum visibility for your research

Submit your manuscript at www.biomedcentral.com/submit
() BioMed Central 